\title{
Profile and pattern of crack consumption among inpatients in a Brazilian psychiatric hospital
}

\author{
Perfil e padrão de consumo de crack em pacientes internados em um hospital \\ psiquiátrico brasileiro
}

\author{
Silvia Mendes da Cunha, ${ }^{1}$ Renata Brasil Araujo, ${ }^{2}$ Lisiane Bizarro $^{3}$
}

\begin{abstract}
Introduction: Crack cocaine use is associated with polydrug abuse, and inpatients dependent on crack exhibit profiles of serious consumption patterns. Use of alcohol and tobacco and other drugs is a risk factor for experimentation of additional drugs, including crack cocaine.

Objectives: The present study describes the characteristics and crack consumption patterns among inpatients in treatment during 2011 and 2012 at the Hospital Psiquiátrico São Pedro (Porto Alegre, Brazil). An additional objective was to identify the sequence of alcohol and tobacco consumption prior to crack use.

Methods: The participants were 53 male inpatients addicted to crack with a mean age of $27.5 \pm 7.3$ years. A sociodemographic questionnaire; the Alcohol, Smoking and Substance Involvement Screening Test and the Mini Mental State Examination were all administered to participants. Inclusion criteria were crack cocaine dependency (based on the 10th edition of the International Classification of Diseases [ICD-10]) and being abstinent for 7 days. Patients with cognitive difficulties who were unable to understand and/or respond to the questionnaires were excluded from the sample.

Results: The participants were young male adults with low educational level and low incomes and were polydrug users. The majority had made more than one attempt to quit. Use of legal drugs in early adolescence, prior to crack use, was identified.

Conclusions: The profiles of the inpatients addicted to crack treated at this hospital indicate a serious usage pattern among those who seek specialized support. Crack use is frequent and is associated with use of other drugs and with difficulty sustaining abstinence. The pattern of progression from alcohol and tobacco use to crack cocaine dependency demands the attention of those responsible for prevention policies.
\end{abstract}

Keywords: Consumption pattern, drug addiction, crack cocaine.

\section{Resumo}

Introdução: $O$ uso de crack continua associado ao abuso de múltiplas drogas, e o perfil do dependente de crack em tratamento tipo internação parece estar relacionado a um padrão grave de consumo. O consumo de álcool, tabaco e outras drogas é um fator de risco para a experimentação de novas drogas, como o crack.

Objetivos: Descrever características e padrão de consumo do crack em pacientes em tratamento tipo internação no Hospital Psiquiátrico São Pedro (Porto Alegre, Brasil) nos anos de 2011 e 2012. Além disso, identificar a sequência de consumo de álcool e cigarro prévio ao crack.

Método: Participaram do estudo 53 homens dependentes de crack, com média de idade de $27.5 \pm 7.3$ anos. Os participantes responderam a um questionário sociodemográfico, ao Alcohol, Smoking and Substance Involvement Screening Test e ao Mini Exame do Estado Mental. Os critérios de inclusão foram: dependência de cocaine (crack) baseada na $10^{a}$ edição da Classificação Internacional de Doenças (CID-10) e estar há mais de 7 dias em abstinência. Pacientes que apresentavam prejuízos cognitivos ou dificuldades de compreensão para o entendimento dos questionários foram excluídos da amostra.

Resultados: Os participantes eram adultos jovens, com baixa escolaridade e renda, poliusuários de drogas. A maioria dos participantes realizou mais de uma tentativa de parar o consumo. Uso de drogas lícitas no início da adolescência, antes da experimentação do crack, foi identificado.

Conclusões: O perfil do dependente de crack tratado nesse hospital aponta para um grave padrão de consumo entre usuários que procuram assistência. $\mathrm{O}$ uso continua frequente, associado ao consumo de outras drogas e à dificuldade de manter-se em abstinência. $O$ padrão de progressão do uso de álcool e tabaco para a dependência de crack requer atenção quanto a políticas de prevenção.

Descritores: Padrão de consumo, dependência química, cocaína crack.

\footnotetext{
${ }^{1}$ Psychologist. PhD in Psychology from Instituto de Psicologia, Universidade Federal do Rio Grande do Sul (UFRGS), Porto Alegre, RS, Brazil. ${ }^{2}$ Psychologist. PhD in Psychology from Pontifícia Universidade Católica do Rio Grande do Sul (PUCRS), Porto Alegre, RS, Brazil. Hospital Psiquiátrico São Pedro (HPSP), Porto Alegre, RS, Brazil. ${ }^{3}$ Psychologist. PhD in Psychology from the Institute of Psychiatry, King's College London, London, UK. Instituto de Psicologia, UFRGS, Porto Alegre, RS, Brazil. This article is part of the first author's doctoral dissertation presented to the Graduate Program in Psychology, Universidade Federal do Rio Grande do Sul (UFRGS), Porto Alegre, RS, Brazil, entitled "Viés atencional e fissura para pistas associadas ao consumo de crack em dependentes em tratamento" (Attentional bias and cue-induced crack craving related to the consumption of crack in dependent patients receiving treatment).

Financial support: Coordenação de Aperfeiçoamento de Pessoal de Nível Superior (CAPES).

Submitted Oct 04 2014, accepted for publication May 04 2015. No conflicts of interest declared concerning the publication of this article.

Suggested citation: Cunha SM, Araujo RB, Bizarro L. Profile and pattern of crack consumption among inpatients in a Brazilian psychiatric hospital. Trends Psychiatry Psychother. 2015;37(3):126-132. http://dx.doi.org/10.1590/2237-6089-2014-0043
} 


\section{Introduction}

Use of crack cocaine in Brazil has been growing over the last two decades. ${ }^{1}$ Crack, or freebased cocaine, is a volatile form of stimulant drug that can be smoked in a pipe when heated. Cocaine is absorbed through the lungs, moving quickly to the heart and brain. ${ }^{2}$ The result is that crack has a high potential for dependency. ${ }^{1}$ The main effects of chronic use of crack include aggression, decreased self-care, insomnia, propensity to lung infections, weight loss, tremors, seizures, strokes, psychosis, confused states and diseases. ${ }^{3}$

Moreover, crack addicts are at a higher risk of death than the general population; homicide and AIDS are the most frequent causes. ${ }^{4,5}$ The neuropsychological impairments $^{6}$ that result from the progressive effects of crack use include deficits in intellectual abilities and slower psychomotor processing. ${ }^{7}$ Psychosocial problems, such as poor self-care, family problems, disruption of social and emotional bonds, job loss and exposure to risk behaviors are also observed among crack addicts. ${ }^{8,9}$

During the 1990s, crack users became the largest group of patients in hospital outpatient drug dependency treatment clinics. ${ }^{10}$ By the 2000s, crack had become the most prevalent illicit drug used among inpatients in a psychiatric hospital for treatment of drug dependency. ${ }^{11}$ In a study that analyzed data from an inpatient facility for drug dependency in Porto Alegre, Brazilian researchers found an increase in hospital admissions of crack addicts; the percentage grew from 21.8 to $61.9 \%$ of all patients admitted from 2002 to $2006 . .^{12}$ Attempting to deal with this problem, in 2010 the Brazilian government launched the Plano Integrado de Enfrentamento ao Crack e Outras Drogas (Integrated Plan for Combating Crack and Other Drugs). In 2011, it initiated the program Crack é Possível Vencer (Crack Can be Beaten), which comprises measures for prevention, treatment, social reintegration, and tackling drug trafficking. ${ }^{13}$

An article profiling cocaine and crack users in Brazil ${ }^{14}$ reported that typical crack users were young adult men with poor education and low incomes who had social and health problems associated with their consumption and that onset of abuse often occurs during adolescence. Although consumption of crack is more prevalent among low-income individuals, it has increased in all social classes in Brazil. ${ }^{9}$ Easy access to crack in São Paulo was described in the 2000s, including strategies by the trafficking market to increase accessibility, such as home delivery. ${ }^{15}$ In Porto Alegre, consumption of crack cocaine has increased since 2001 and crack addicts have reported that the drug is supplied from São Paulo. ${ }^{5}$

Previous research with crack inpatients, conducted at the Hospital Psiquiátrico São Pedro (HPSP), described the profile of users as single young adults with poor education, low incomes and dependency on and abuse of other drugs. ${ }^{16}$ Crack-dependent inpatients in Porto Alegre have reported using other psychoactive substances ${ }^{17}$ and describe consumption of crack mixed with tobacco or marijuana. ${ }^{18}$ In the southern region of Brazil it has been found that crack-dependent patients treated at either health centers ${ }^{19}$ or therapeutic communities ${ }^{18}$ used tobacco, alcohol, and other drugs prior to onset of their crack use. This progressive pattern of drug use from legal to illegal drugs has also been described elsewhere in the literature. ${ }^{14,20}$ The first substances used by crack-dependent inpatients are alcohol and tobacco, ${ }^{21}$ which is reported to begin at 12 to 13 years of age. ${ }^{17}$ Recently, another study revealed that nicotine acts as a gateway drug and has a potential priming effect for cocaine in the sequence of drug use.22 Additionally, the same study found a biological and molecular mechanism to explain these patterns; priming with nicotine enhanced the effects of cocaine in the reward circuitry and in expression of the fosB gene. ${ }^{22}$

Compulsive binging (consuming large amounts in a short period) is the most common pattern of crack consumption $^{8}$ and it indicates physical, social, and psychological commitments to the drug. ${ }^{23}$ The literature on frequency of crack consumption defines sporadic use as up to 2 days a week and frequent use as 3 to 4 days a week, while a heavy use pattern is characterized as consumption of crack 5 to 7 days a week. ${ }^{24}$

Crack addicts seek help at hospitals in times of crisis, but there is little adherence to outpatient treatment. A follow-up of 107 São Paulo patients 12 years after discharge from treatment for detoxification revealed that $20.6 \%$ had died, $10 \%$ had been arrested, $32.8 \%$ were abstinent, and $16.8 \%$ regularly used the substance. Mortality was related to violent causes and there was migration from crack use to other drugs such as marijuana and snorted cocaine. ${ }^{24}$ Furthermore, the profile of crack users seeking treatment shows that they are heavier drug abusers than other types of drug users and that onset of use tends to occur earlier in life. ${ }^{14}$

The objective of this study was to establish a profile of the pattern of crack consumption by inpatients at the HPSP in Porto Alegre over an 8-month period spanning 2011 and 2012. An additional objective was to identify sequential consumption of licit substances prior to crack use. The study hypothesis was that the profile would remain the same as that revealed by previous data, but we also intended to look for changes and to describe the current situation of inpatients at this institution. It was also considered plausible that a progressive pattern of drug consumption would be observed. 


\section{Method}

\section{Participants}

The study enrolled 53 men addicted to crack cocaine with a mean age of $27.5 \pm 7.3$ years. Participants were inpatients at the HPSP in 2011 and 2012. The HPSP is a public hospital and the patients were residents of Porto Alegre, the Porto Alegre metropolitan region or other parts of the state of Rio Grande do Sul. Sample selection was by convenience and was not probabilistic. ${ }^{25}$ Participants also used, abused or were dependent on other psychoactive substances, so we established that for inclusion their crack dependency had to be of greater relevance to consumption and to its associated problems. These data were obtained from participants' medical records. The 10th edition of the International Classification of Diseases (ICD-10), published by the World Health Organization in $1993,{ }^{26}$ was used to establish the criteria for addiction to cocaine (crack).

Other inclusion criteria were the ability to read and write and abstinence for more than 7 days. This minimum withdrawal period was proposed to reduce participants' possible difficulties with understanding the research instruments. ${ }^{17}$ Patients with psychotic symptoms were not included in the study. These data were obtained by speaking with the reporting staff and noting the information from patients' charts. Likewise, patients with cognitive difficulties that would affect their responses to the questionnaires were not included in the sample. These data were obtained by administration of the Mini Mental State Examination (MMSE).

\section{Instruments}

1. The MMSE was used to assess cognitive function and presence of dementia. ${ }^{27}$ It consists of a global cognitive assessment that quickly evaluates cognitive domains such as orientation to time and space and abilities for immediate memory recall, attention, language, and visuospatial skills. ${ }^{28}$ We used a modified Brazilian version ${ }^{28}$ and established cutoff points according to educational level: illiterate $=20$ points, from 1 to 4 years of education $=25$ points, from 5 to 8 years of education $=26$ points, from 9 to 11 years of education $=28$ points, and the cutoff point for individuals who had spent more than 11 years in education was $29 .{ }^{29}$ Number of years in education was defined using the last year of schooling that had been completed (not counting possible grade repetition).

2. A questionnaire on sociodemographic data was used to characterize the sample. Questions were included that identified participants' age, marital status, economic status, age at onset of crack use, duration of crack use, number of attempts to stop using the substance and use of medications and general health condition.

3. The Alcohol, Smoking and Substance Involvement Screening Test (ASSIST) was administered to screen participants for involvement with alcohol, tobacco and other substances. This test was developed as part of a multicenter study coordinated by the World Health Organization and has been validated in Brazil. ${ }^{30}$ The questionnaire contains eight questions about nine kinds of psychoactive substances. Each response corresponds to a score from 0 to 4 and the sum can vary from 0 to 20 . Scores 0-3 indicate occasional use, 4-15 are indicative of abuse, and scores greater than or equal to 16 suggest dependence.

\section{Ethical procedures and data collection}

Ethical considerations for research involving human beings were respected and confidentiality of the subjects' identities was ensured. These findings are part of a larger study that forms the basis for the first author's doctoral thesis, which is currently unpublished. The study was approved by the Ethics Committees at the HPSP and the Institute of Psychology at the Universidade Federal do Rio Grande do Sul, both in Brazil. Data collection was conducted over an 8-month period spanning 2011 and 2012. The questionnaires/ instruments used in this study were administered in individual sessions, in an appropriate environment on the HPSP premises. The two interviewers, one psychologist and one psychology student, were duly trained in advance. Patients' participation was voluntary and took place during their free time from the hospital routine and they were invited to enroll on the study by the interviewers after previously being cleared by hospital staff. Initially, the MMSE was administered to participants who had been pre-selected to participate in the study and those who met the cutoff criteria established for the instrument were eligible for administration of the other instruments, while those who did not meet the MMSE requirements were not included in the study. Participants were provided with pencils and paper to execute tasks requiring writing and drawing skills and an interviewer recorded the answers they provided on the pencil and paper versions.

Assessments were conducted on days and times that did not interfere with the activities and routines of the treatment unit and all participants signed informed consent agreements. Data collection was carried out individually by a trained research assistant in an appropriate environment, and any questions raised by the participants were answered. 


\section{Statistical analysis}

Sociodemographic characteristics, consumption profile and levels of use, abuse, and dependence on psychoactive substances were analyzed in terms of frequency and distribution. The Statistical Package for Social Sciences (SPSS $®$ ), version 18, was used for data analysis.

\section{Results}

\section{Sociodemographic data}

Most of the participants were single $(81.1 \%, n=43)$ and $43 \%(n=23)$ were parents. Some participants had some kind of job (39.6\%; $n=21)$. Most had low levels of education $(58.5 \%$ had not completed elementary school; $24.5 \%$ had only completed elementary school).

Participants' (71\%) most frequently reported monthly income bracket was 2 to 4 times the Brazilian minimum wage.

\section{Consumption profile}

Regarding number of cessation attempts, only $17 \%(n=9)$ of the sample reported that the current hospitalization was their first attempt to stop taking crack. On average, participants had had $3 \pm 3.2$ specialized treatments previous to the current hospitalization, with a range of 0 to 13 previous treatments. They had made a mean of $5 \pm 8.5$ previous cessation attempts, and the number of prior attempts reported ranged from 0 to 60 . These attempts did not necessarily involve professional support (Table 1 ).

First use of tobacco took place earlier (mean \pm standard deviation $=11 \pm 5.3$ years) than first use of alcohol (13 \pm 3.33 years). The ASSIST results identified abuse of and dependence on tobacco ( $83 \%$ abuse and $3.8 \%$ dependence), alcohol (64.2\% abuse and $9.3 \%$ dependence) and marijuana (53.7\% abuse and $1.9 \%$ dependence). In contrast, most patients had not used stimulants, inhalants, or hallucinogens (Table 2).

\section{Discussion}

Continuous mapping of usage patterns can be used to support development and implementation of treatment guidelines for crack cocaine addiction in Brazil. ${ }^{9}$ Despite the growth in consumption of and dependence on this substance in Brazil, ${ }^{11,15}$ the present study shows that little has changed in the profile of inpatients at the HPSP. The results are similar to those from a previous study conducted at the same hospital in $2007 . .^{30}$ In that study, the mean age (27.3 \pm 6.65 years) was almost identical to the average age of the patients in this study, the mean age of onset of consumption was $23.87 \pm 6.47$ years, most participants were single and also reported consumption of alcohol, tobacco and marijuana. Inpatients in both studies had low incomes. According to the stratification of income levels defined by the Brazilian Institute of Geography and Statistics (IBGE), most participants were

Table 1 - Profile of crack use

\begin{tabular}{|c|c|c|c|}
\hline Variable & Mean \pm SD & Minimum & Maximum \\
\hline Age at first use & $21 \pm 7.73$ & 11 & 48 \\
\hline Last intake (days) & $22.08 \pm 12.66$ & 12 & 66 \\
\hline Years using & $5.8 \pm 3.54$ & 1 & 18 \\
\hline Amount used in the last week of use (number of rocks) & $64.42 \pm 43.54$ & 10 & 168 \\
\hline Days of consumption in the last week of use & $5.41 \pm 1.39$ & 2 & 7 \\
\hline Largest abstinence period (days) & $232.21 \pm 304$ & 8 & 1620 \\
\hline
\end{tabular}

$\mathrm{SD}=$ standard deviation.

Table 2 - Results for use and abuse of and dependence on other drugs according to scores on the Alcohol, Smoking and Substance Involvement Screening Test (ASSIST)

\begin{tabular}{|c|c|c|c|c|c|c|c|}
\hline & $\begin{array}{c}\text { Tobacco } \\
\%(n)\end{array}$ & $\begin{array}{l}\text { Alcohol } \\
\% \text { (n) }\end{array}$ & $\begin{array}{c}\text { Marijuana } \\
\% \text { (n) }\end{array}$ & $\begin{array}{c}\text { ST } \\
\%(n)\end{array}$ & $\begin{array}{c}\text { IN } \\
\%(n)\end{array}$ & $\begin{array}{c}\text { HAL } \\
\%(n)\end{array}$ & $\begin{array}{c}\text { Cocaine } \\
\%(n)\end{array}$ \\
\hline Does not use & $9.4(5)$ & $1.9(1)$ & $7.4(4)$ & $81.5(44)$ & $66.7(36)$ & $85.2(46)$ & - \\
\hline Uses & $3.8(2)$ & $24.5(13)$ & 35.2 (19) & $14.8(8)$ & $27.8(15)$ & $11.1(6)$ & - \\
\hline Abuses* & $83(44)$ & $64.2(34)$ & $53.7(29)$ & $1.9(1)$ & $3.7(2)$ & $1.9(1)$ & $37.7(20)$ \\
\hline Dependent & $3.8(2)$ & $9.3(5)$ & $1.9(1)$ & - & - & - & $62.3(33)$ \\
\hline
\end{tabular}

$\mathrm{HAL}=$ hallucinogens; IN = inhalants; ST = stimulants.

* Suggestive of tobacco abuse according to scores in Alcohol, Smoking and Substance Involvement Screening Test (ASSIST); not considering diagnoses of abuse and dependence according to the Diagnostic and Statistical Manual of Mental Disorders, Fourth Edition, Text Revision (DSM-IV-TR) or of harmful use and dependence syndrome according to the ICD-10. 
classified as Class D (earning between 2 and 4 times the Brazilian minimum wage). The 2007 study found highest prevalence in the income range equal to 1.42 times the minimum wage. ${ }^{31}$ Another previous study, using the equivalent income indicator, reported an average income of 1.46 times the minimum wage. ${ }^{32}$ In contrast, a study in 2012 found two groups of crack-dependent individuals, equally divided across high and low classes, but these groups did not differ in terms of pattern of use, or intensity or frequency of consumption. ${ }^{17}$

A current study at the HPSP found a similar pattern of age and educational level and the same profile of marital status among crack addicts. ${ }^{16}$ Regarding the level of education, the results agree with previous studies that have identified low education levels among inpatients, ${ }^{33}$ users in the community, ${ }^{15,34}$ and outpatients. ${ }^{19,35}$ In the present study, the most common educational level among participants was incomplete elementary education, but the previous study at HPSP reported an average of 9.4 years of schooling. ${ }^{31}$ It is not possible to determine whether these 9 years of study in the 2007 survey included grade repetition.

In both the present and previous studies conducted at the HPSP, several prior cessation attempts were identified. ${ }^{31}$ Unfortunately, the previous reported consumption pattern of $11.57 \pm 7.85$ rocks per day is not directly comparable with data from the present study. Notwithstanding, the result of this study, a weekly consumption of 64 rocks, is not very different. Despite difficulties in accurately comparing the results of the two studies, a persistent pattern of high frequency of use was identified in both. In the present study, participants used crack on average 5 days a week, while in the previous study, ${ }^{31} 70 \%$ of the sample used it daily and $20 \%$ used it weekly.

In a retrospective study comparing clinical data from the HPSP for 2002 and 2006, the authors observed a change in the profile of patients. In 2006 there were fewer hospitalizations for alcoholism and a significant increase in admissions for crack use with other drugs. ${ }^{12}$ It is suggested that the profile of crack-addicted inpatients remains similar ${ }^{17}$ and is in accordance with other studies that have identified young, single men in therapeutic communities $^{18,36}$ and in Psychosocial Care Centers (Centros de Atenção Psicossocial, CAPS) in the Porto Alegre metropolitan area. ${ }^{19}$ Persistent sampling bias is also possible, with underestimation of the numbers of crack users in other segments of health care.

Most studies ${ }^{17,19,31,34}$ indicate that the start of crack use occurs on average after the age of 18 . Although there are reports of onset during adolescence in therapeutic communities, ${ }^{18}$ most studies point to users beginning consumption as they enter adulthood. Transition to adulthood appears to be a risk factor for addiction to cocaine. A recent study at the HPSP found a progressive pattern of drug use, passing from licit to illicit drugs, and the authors pointed out that marijuana was the first illicit drug consumed. ${ }^{16}$

In this study, we confirm the sequential pattern of drug use that begins with premature experimentation with tobacco and alcohol, evolving into experimentation with marijuana during adolescence and progressing to late onset of cocaine use, in agreement with previous data from a similar population. ${ }^{17,33}$ However, it is impossible to distinguish between snorted or injected cocaine and crack-crack use in our data. Progression to drug use is associated with factors such as peer pressure, the search for new sensations and the influence of drug trafficking, ${ }^{21}$ in addition to biological and molecular factors. ${ }^{22}$

Given repeated findings indicating escalation of use from licit drugs to illicit drugs, it is important to reflect on the relevance of preventive approaches to early use of marijuana, tobacco and alcohol. Not surprisingly, the final pattern can be described as polydrug use; tobacco, alcohol and marijuana have the highest percentage of abuse, which is a pattern that has also been observed in studies conducted in several different places. ${ }^{15,33-35}$ In view of the expansion of the crack market and the lack of consensus on the effectiveness of treatment, ${ }^{37}$ early prevention of tobacco and alcohol use among children and adolescents could prevent the progression to illicit substances. ${ }^{24}$ Prevention programs that encourage selfcontrol and coping and social skills are important in the context of adolescence. ${ }^{38}$

The answers given to the ASSIST test demonstrate that these patients had a profile of abuse of and dependence on other substances, which is similar to previous studies. ${ }^{16,39}$ In one such study it was found that $96.33 \%$ of the sample exhibited marijuana dependence. It should be noted that the ASSIST does not allow for inferences of an accurate diagnosis of abuse and dependence according to the Diagnostic and Statistical Manual of Mental Disorders, Fourth Edition, Text Revision (DSM-IV-TR) or of harmful use and dependence syndrome according to ICD-10 criteria, which means that comparison with other studies in this field is not possible. It is however possible that the participants identified by the ASSIST abuse criteria would be diagnosed as dependent if evaluated using more robust criteria such as the DSM-IV-TR or ICD-10 criteria. Furthermore, in contrast to the profile of progression from licit drug use to crack use, there are also crack dependent, polydrug users who begin to consume other substances after having already become dependent on crack. In such cases, multiple substances are employed to control the negative and positive effects of crack, such as depressed 
mood and intense euphoria. This pattern is an obstacle to successful treatment and it increases the severity of the psychiatric condition. ${ }^{23}$ The use of other drugs such as alcohol and tobacco can trigger a relapse when a user is abstinent from crack. Crack craving is related to craving for tobacco and can be triggered by alcohol consumption. ${ }^{32}$

Even though sporadic consumers were also identified in this study, a pattern of heavy consumption was detected. ${ }^{24} \mathrm{~A}$ previous study showed average consumption of 8 and 12 rocks per day in the cities of Salvador and Rio de Janeiro respectively. ${ }^{34}$ A study reporting the previous standard consumption of inpatients assessed amount of consumption, in terms of weekly use, at $16.5 \pm 18.93$ grams. ${ }^{33}$ Horta et al. ${ }^{19}$ did not report the amount consumed in their 2011 study, but did report results of daily to 6 days a week usage among individuals dependent on crack surveyed in the CAPS. Taking this into consideration for extrapolation purposes, it becomes clear that the pattern of consumption reported by participants in the present survey is similar to other studies. However, the magnitude of consumption is reported in terms of weekly and not daily use and in terms of rocks consumed.

In agreement with other findings, it was confirmed that those who are dependent on crack make several unsuccessful attempts to quit, including seeking care from specialists. Attempts to maintain abstinence start during outpatient treatment and progress to include treatments in hospitals. ${ }^{33,40}$ Inpatients reported 5 cessation attempts in the present study and more than 3 hospitalizations in a previous study. ${ }^{17}$ One of the characteristics of crack dependence is the number of relapses after treatment and the difficulty of maintaining abstinence. The relapse may be related to factors such as the social environment. ${ }^{37}$ Interventions focused on relapse prevention should take into account environmental triggers in control and management of craving. The main triggers crack addicts reported are alcohol use, having money to spare, seeing other users consuming, and experiencing negative emotions. ${ }^{32}$

Similar to results published elsewhere, in this study the average period of consumption was 5 years. ${ }^{34}$ Another recent study with HPSP inpatients observed an average of 6.93 years of use and several previous attempts to quit, including hospitalizations. ${ }^{16}$ The average period for which abstinence from crack was sustained was a little less than 1 year (232 days), which is almost identical to a study published in 2010 by Araujo et al., ${ }^{33}$ in which the average period was 201 days. A heavy consumption pattern with concomitant use of multiple substances develops after a few years, causing difficulties in adherence to treatment.
Crack-dependent inpatients present severe patterns of consumption and, therefore, are more likely to have suffered negative consequences than groups who have initiated consumption recently. A study comparing crack users undergoing treatment with untreated users found key significant differences between groups. One of the differences identified in that study was that the group in treatment had higher socioeconomic levels and heavier usage, while not being in treatment was associated with more housing problems, lighter consumption and being a novice user. ${ }^{41}$ There are low numbers of crackdependent individuals in treatment, in contrast to the great demand, revealing difficulty in providing access to treatment centers. ${ }^{41}$

The present study was able to demonstrate a heavy pattern of consumption, with negative characteristics, such as a large proportion of polydrug users and escalation from licit to illicit substances, in accordance with the hypothesis. Furthermore, the findings validate previous studies about crack-dependent profiles. Authors of one study conducted in the city of Rio de Janeiro drew attention to low numbers of dependent individuals in treatment, in relation to the great demand for treatment and the urgency of the need for increased access to treatment centers. ${ }^{41}$ The present study resembles the previous study ${ }^{29}$ and another recent study, ${ }^{16}$ both of which were conducted at the HPSP. All three of these studies found characteristics in common in the profiles of crack-dependent inpatients in treatment - young adult polydrug users with low incomes who have made previous attempts to stop and who exhibit high frequency drug abuse.

One limitation of this present study is its inability to show causal relationships between variables or provide a basis for other inferential analyses. However, the study was designed as a descriptive survey, comparing the data collected with previous literature. Additionally, consumption rate was calculated on a weekly, rather than daily basis. We therefore suggest that future profile studies also determine daily consumption rates to provide a better basis for comparison with other studies in this area. Furthermore, the use of ASSIST is also a limiting factor because it cannot provide an accurate diagnosis of dependence on drugs, and only offers screening indicative of use and abuse of drugs and of dependence on drugs. The ASSIST can be a useful tool in a first screening in primary health care services ${ }^{30}$ and research, but has limitations compared to DSM-IV-TR and ICD-10 diagnoses.

One final limiting factor affecting the results is the fact that the group of participants was composed of patients from a public hospital, all of whom were male. To eliminate this limitation and to enable a wider-ranging 
investigation, it is recommended that future studies include participants from diverse treatment centers (public and private) and also study untreated (active) users. Also, since this study only investigated male crack users, it would also be of interest to analyze differences in profile and consumption patterns between male and female crack users in the city of Porto Alegre. Moreover, studies designed with the objective of mapping the profiles and crack consumption patterns of adolescents in the city would provide data useful for proposing strategies to combat this problem in its early stages.

\section{References}

1. Pulcherio G, Stolf AR, Pettenon M, Fensterseifer DP, Kessler F. Crack - da pedra ao tratamento. Rev AMRIGS. 2010;54:337-43.

2. Masur J, Carlini, EA. Drogas: subsídios para uma discussão. São Paulo: Brasiliense; 2004.

3. Figlie N, Bordin S, Laranjeira R. Aconselhamento em dependência química. São Paulo: Roca; 2004.

4. Ribeiro M, Dunn J, Sesso R, Dias AC, Laranjeira R. Causes of death among crack cocaine users. Rev Bras Psiquiatr. 2006;28:196202.

5. Inciardi JA, Surrat HL, Pechansky F, Kessler F, von Diemen L, da Silva EM, et al. Changing patterns of cocaine use and HIV risks in the south of Brazil. J Psychoactive Drugs. 2006;38:305-10.

6. Kolling NM, Silva CR, Carvalho JCN, Cunha SM, Kristensen $\mathrm{CH}$. Avaliação neuropsicológica em alcoolistas e dependentes de cocaína. Aval Psicol. 2007;6:127-37.

7. Lavtala A, Castaneda AE, Peräla J, Saarni SI, Aälto-Setala T, Lönnqvist J, et al. Cognitive functioning in substance abuse and dependence: a population-based study of young adults. Addiction. 2009;104:1558-68.

8. Chaves TV, Sanchez ZM, Ribeiro LA, Nappo SA. Fissura por crack: comportamentos e estratégias de controle de usuários e exusuários. Rev Saude Publica. 2011;45:1168-75.

9. Rodrigues DS, Backes DS, Freitas HMB, Zamberlan C, Ghellen $\mathrm{MH}$, Colomé JS. Conhecimentos produzidos acerca do crack: uma incursão em dissertações e teses brasileiras. Cienc Saude Coletiva. 2012;17:1247-58.

10. Dunn J, Laranjeira R, Da Silveira DX, Formigoni ML, Ferri CP. Crack cocaine: an increase in use among patients attending clinics in São Paulo: 1990-1993. Subst Use Misuse. 1996;31:519-27.

11. Borini P, Guimarães RC, Borini SB. Usuários de drogas ilícitas internados em hospital psiquiátrico: padrões de uso e aspectos demográficos e epidemiológicos. J Bras Psiquiatr. 2003;52:171-9.

12. Formiga LT, Santos RCS, Dumcke TS, Araújo RB. Comparação do perfil de dependentes químicos internados em uma unidade de dependência química de Porto Alegre/RS em 2002 e 2006. Rev HCPA. 2009;29:120-6.

13. Brasil, Secretaria Nacional Antidrogas (SENAD), Fundação Osvaldo Cruz (FIOCRUZ). Estimativa do número de usuários de crack e/ou similares nas capitais do país. Brasília: Rio de Janeiro; 2013.

14. Dualibi LB, Ribeiro M, Laranjeira R. Profile of cocaine and crack users in Brazil. Cad Saude Publica. 2008;24:s545-57.

15. Oliveira LG, Nappo SA. Crack na cidade de São Paulo: acessibilidade, estratégias de mercado e formas de uso. Rev Psiquiatr Clin. 2008;35:212-8.

16. Balbinot $A D$, Araújo RB. Análise do perfil de dependentes de crack em internação hospitalar. Saude Pesq. 2012;5:471-80.

17. Freire SD, Santos $P L$, Bortolini $M$, Moraes JFD, Oliveira MS. Intensidade e uso de crack de acordo com a classe econômica de usuários internados na cidade de Porto Alegre/Brasil. J Bras Psiquiatr. 2012;61:221-6.

18. Seleguim MR, Oliveira MLF. Padrão do uso de drogas de abuso em usuários de crack em tratamento em uma comunidade terapêutica. Rev Neurocienc. 2013;21:339-48.

19. Horta RL, Horta BL, Rosset AP, Horta CL. [Crack cocaine users who attend outpatient services]. Cad Saude Publica. 2011;27:226370 .
20. Kandel D. Stages in adolescent involvement in drug use. Science. 1975; 190:912-4.

21. van der Meer Sanchez Z, Nappo SA. [Progression on drug use and its intervening factors among crack users]. Rev Saude Publica. 2002;36:420-30.

22. Kandel DB, Kandel ER. A molecular basis for nicotine as a gateway drug. N Engl J Med. 2014;371:2038-9.

23. Oliveira LG, Nappo SA. [Characterization of the crack cocaine culture in the city of São Paulo: a controlled pattern of use]. Rev Saude Publica. 2008;42:664-71.

24. Dias AC, Araújo MR, Laranjeira R. Evolução do consumo de crack em coorte com histórico de tratamento. Rev Saude Publica. 2011;45:938-48.

25. Cozby PC. Métodos de pesquisa em ciências do comportamento. São Paulo: Atlas; 2003.

26. Organização Mundial de Saúde (OMS). Classificação de transtornos mentais e de comportamento da CID-10: descrições clínicas e diretrizes diagnósticas. Porto Alegre: Artmed; 1993.

27. Lourenço RA, Veras RP. [Mini-Mental State Examination: psychometric characteristics in elderly outpatients]. Rev Saude Publica. 2006;40:712-9.

28. Fernandes Rde C, da Silva KS, Bonan C, Zahar SE, Marinheiro LP. [Cognitive function in menopausal women evaluated with the Mini-Mental State Examination and Word-List Memory Test]. Cad Saude Publica. 2009;25:1883-93.

29. Brucki SM, Nitrini R, Caramelli P, Bertolucci PH, Okamoto IH. [Suggestions for utilization of the mini-mental state examination in Brazil]. Arq Neuropsiquiatr. 2003;61:777-81.

30. Henrique IFS, De Micheli D, Lacerda RB, Lacerda RA, Formigoni ML. [Validation of the Brazilian version of Alcohol, Smoking and Substance Involvement Screening Test (ASSIST)]. Rev Assoc Med Bras. 2004;50:199-206.

31. Guimarães C, Santos D, Freitas R, Araújo R. Perfil do usuário de crack e fatores relacionados a criminalidade em unidade de internação para desintoxicação no Hospital Psiquiátrico São Pedro de Porto Alegre (RS). Rev Psiquiatr Rio Gd Sul. 2008;30:101-8.

32. Zeni TC, Araújo RB. Relação entre o craving por tabaco e o craving por crack em pacientes internados para desintoxicação. J Bras Psiquiatr. 2011;60:28-33.

33. Araújo RB, Pansard M, Boeira BU, Rocha NS. As estratégias de coping para o manejo da fissura entre os dependentes de crack. Rev HCPA. 2010;30:36-42.

34. Santos Cruz M, Andrade T, Bastos FI, Leal E, Bertoni N, Vilar LM, et al. Key drug use, health and socio-economic characteristics of young crack users in two Brazilian cities. Int J Drug Policy. 2013;24:432-8.

35. Vargens RW, Cruz MS, Santos MA. Comparação entre usuário de crack e outras drogas em serviço especializado de hospital universitário. Rev Latino-Am Enfermagem. 2011;19:804-12.

36. Scheffer M, Pasa GG, Almeida RMM. Atenção, ansiedade e raiva em dependentes químicos. PSICO. 2009;40:235-44.

37. Rodrigues VS, Horta RL, Szupszynski KP, Souza MC, Oliveira MS. Revisão sistemática sobre tratamentos psicológicos para problemas relacionados ao crack. J Bras Psiquiatr. 2012;62:20816.

38. Wagner MF, Oliveira MS. Estudo das habilidades sociais em adolescentes usuários de maconha. Psicol Estud. 2009;14:10110.

39. Lewgoy LB, Vischer VJ, Operamman CMO, Araújo RB. Padrão de uso de cannabis em dependentes de crack/cocaína internados para desintoxicação. Clin Biomed Res. 2014;34;274-80.

40. Pedroso RS, Kessler F, Pechansky F. Treatment of female and male inpatient crack users: a qualitative study. Trends Psychiatry Psychother. 2013;35:36-45.

41. Cruz M, Bertoni N, Bastos FI, Burnett C, Gooch J, Fischer B. Comparing key characteristics of young adult crack users in and out of treatment in Rio de Janeiro, Brazil. Subst Abuse Treat Prev Policy. 2014;9:2.

\section{Correspondence:}

Silvia Mendes da Cunha

Instituto de Psicologia UFRGS

Rua Ramiro Barcelos, 2600, sala 105

90035-003 - Porto Alegre, RS - Brazil

E-mail: silvia_mcunha@yahoo.com.br 